\title{
HUBUNGAN KOMUNIKASI PEMBELAJARAN SISTEM E-LEARNING DENGAN MOTIVASI BELAJAR SISWA \\ (KASUS PADA SMK WIKRAMA KOTA BOGOR)
}

\section{RELATIONSHIP OF LEARNING COMMUNICATION E-LEARNING SYSTEM WITH STUDENT MOTIVATION OF LEARN (CASE AT SMK WIKRAMA KOTA BOGOR)}

\author{
R Prayogi', U Suryatna ${ }^{2}$, AA Kusumadinata ${ }^{3 a}$ \\ ${ }^{1}$ Alumni Ps. Ilmu Komunikasi, Fakultas Ilmu Sosial dan Ilmu Politik, Universitas Djuanda Bogor, ${ }^{2}$ Dosen \\ Pembimbing I Program Studi Komunikasi, Fakultas Ilmu Sosial dan Ilmu Politik, ${ }^{3}$ Dosen Pembimbing II \\ Program Studi Komunikasi Universitas Djuanda Bogor, Jl. Tol Ciawi No.1 Kotak Pos 35 Bogor 16720 \\ a Korespondensi: AA Kusumadinata, Email: alialamsyahkusumadinata@gmail.com
}

(Diterima: 07-07-2015; Ditelaah: 10-08-2015; Disetujui: 24-08-2015)

\begin{abstract}
The utilization of information and communication technology in education have been gradually changing the conventional learning communication system to learning with e-learning that utilizies the internet network. Implementation of e-learning system in learning communication could be expected to affect the students' motivation. This study aimed to: (1) to investigate the implementation of learning communication using elearning system, (2) to determine students' motivation, (3) to determine whether there is a relationship between learning communication using e-learning system with student motivation. This study was designed using associative method. The study population is Wikrama vocational students of Bogor, a sample set of 83 students with simple random sampling techniques and data analysis performed using the Spearman Rank correlation test. The result showed that (1) the communication of learning using e-learning system is implemented with a variety of learning methods of communication, efficient, easy to understand and interesting, (2) students' motivation to learning communication using e-learning system is high, and (3) there is a relationship real learning communication system between e-learning with student motivation.
\end{abstract}

Keyword: Learning Communication, E-learning, Motivation to Learn.

\begin{abstract}
ABSTRAK
Pemanfaatan teknologi informasi dan komunikasi dalam bidang pendidikan secara bertahap telah mengubah komunikasi pembelajaran konvensional ke sistem pembelajaran dengan e-learning yang memanfaatkan jaringan internet. Penerapan sistem e-learning dalam komuniasi pembelajaran diduga dapat berpengaruh terhadap motivasi belajar siswa. Penelitian ini bertujuan: (1) untuk mengetahui pelaksanaan komunikasi pembelajaran menggunakan sistem e-learning, (2) untuk mengetahui motivasi belajar siswa, (3) untuk mengetahui apakah terdapat hubungan antara komunikasi pembelajaran menggunakan sistem e-learning dengan motivasi belajar siswa. Penelitian ini didesaion menggunakan metode asosiatif. Populasi penelitian adalah siswa SMK Wikrama Kota Bogor, sampel ditetapkan sebanyak 83 siswa dengan teknik sampling acak sederhana dan analisis data dilakukan dengan menggunakan uji korelasi Rank Spearman. Hasil penelitian menunjukan bahwa (1) komunikasi pembelajaran menggunakan sistem e-learning dilaksanakan dengan metode komunikasi pembelajaran yang bervariasi, efisien, mudah dipahami dan menarik, (2) motivasi belajar siswa dengan komunikasi pembelajaran menggunakan sistem e-learning adalah tinggi, serta (3) terdapat hubungan yang nyata antara komunikasi pembelajaran sistem e-learning dengan motivasi belajar siswa.
\end{abstract}

Kata Kunci: Komunikasi Pembelajaran, E-learning, Motivasi Belajar. 
R Prayogi, U Suryatna, AA Kusumadinata. 2015. Hubungan Komunikasi Pembelajaran Sistem Elearning Dengan Motivasi Belajar Siswa (Studi Pada SMK Wikrama Kota Bogor). Jurnal Komunikatio 1(2): $99-113$. 


\section{PENDAHULUAN}

Perkembangan teknologi informasi dan komunikasi berkembang begitu cepat, merambah ke semua sektor kehidupan. Bahkan perkembangannya diperkirakan lebih pesat dari perkiraan semula. Teknologi informasi dan komunikasi secara cepat dan revolusioner telah merubah pola pikir dan peradaban manusia. Perubahan terbesar dalam kurun waktu 20 tahun terakhir dalam pola-pola interaksi komunikasi terjadi sebagai akibat penemuan dan pertumbuhan internet. Penemuan internet dan pengembangannya yang begitu pesat telah mampu mengubah tatanan komunikasi antar manusia, yang tadinya lebih mengandalkan interaksi tatap muka, kini bergeser kearah penggunaan media, khususnya internet. Penggunaan telepon, faksimile, e-mail, radio, chatting, dan internet dalam teori komunikasi disebut dengan komunikasi medio (Morissan,2013).

Transformasi teknologi komunikasi dan informasi memicu hadirnya metode belajar melalui website (e-learning), dimana belajar melalui sebuah media website yang dirancang oleh sekolah untuk membuat siswa mandiri dan memudahkan siswa dalam belajar, karena berkat e-learning siswa dapat belajar dimana saja dan kapan saja. Jika semula e-learning terkesan sebagai pembelajaran yang pasih, setahap demi tahap hal ini mulai bergeser. Adanya fasilitas forum dan chatting didalam media e-learning mulai mengubah pandangan banyak orang akan pembelajaran melalui website yang aktif. Dukungan multimedia dan perkembangan baru di dunia web semakin membantu mewujudkan pembelajaran interaktif, meskipun tidak bertemu secara fisik. (Prawidilaga, 2013).

Komunikasi pembelajaran sistem e-learning bisa mencakup pembelajaran yang dilakukan di media elektronik (internet) baik secara formal maupun informal. e-learning secara formal contohnya pembelajaran dengan kurikulum, silabus, mata pelajaran dan tes yang telah diatur dan disusun berdasarkan jadwal yang telah disepakati pihak-pihak terkait (pengelola e-learning dan pembelajar sendiri). Pembelajaran seperti ini biasanya tingkat interaksinya tinggi dan diwajibkan oleh pembelajaran jarak jauh yang dikelola oleh instansi pendidikan. Karakteristik e-learning sebagai media pembelajaran diantaranya: (Prawiradilaga, 2013). (1)Memberikan pengalaman belajar yang berbeda dan bervariasi sehingga merangsang minat siswa untuk belajar. (2)Meningkatkan kemampuan siswa dalam bidang teknologi informasi dan komunikasi. (3) Menciptakan situasi belajar yang menyenangkan dan tidak mudah dilupakan siswa. (4) Menjadikan belajar lebih efisien dan bermakna. (5)Komunikasi pembelajaran dilakukan di mana saja dan kapan saja. Komunikasi pembelajaran sistem $e$ learning dapat dikaitkan dengan teori komunikasi massa uses and gratification. Menurut Katz, Blumler, dan Gurevitz dalam (Morissan, 2013) orang secara aktif mencari media tertentu dan muatan (isi) tertentu untuk mencapai kepuasan (hasil) tertentu. Orang dikatakan aktif karena mereka mampu untuk mempelajari dan mengevaluasi berbagai jenis media untuk mencapai tujuan komunikasi.

Menurut Katz ada lima asumsi dasar teori penggunaan dan kepuasan yaitu: (1) Audiensi aktif dan berorientasi pada tujuan ketika menggunakan media, (2) inisiatif untuk mendapatkan kepuasan media ditentukan audiensi, (3) media bersaing dengan sumber kepuasan lain, (4) audiensi sadar sepenuhnya terhadap ketertarikan, motif dan penggunaan media, (5) penilaian isi media ditentukan oleh audiensi. Manfaat komunikasi pembelajaran sistem e-learning itu sendiri menurut Naidu dalam (Prawiradilaga, 2013) adalah : Belajar mandiri online, Belajar mandiri offline, Belajar kelompok secara sinkronus, dan Belajar kelompok asinkronus. Berdasar pada manfaat sebagaimana dikemukakan sebelumnya penggunaan e-learning itu sendiri diduga memiliki hubungan dengan motivasi belajar siswa dalam belajar.

Menurut Katz, Gurevitch dan Haas (dalam Rakhmat, 2007) motivasi timbul akibat adanya dorongan kebutuhan yang harus dipenuhi dalam diri seseorang. Kebutuhan manusia ditentukan oleh lingkungan sosial (social environment) yang dikategorikan sebagai berikut: (1)Kebutuhan kognitif, yakni kebutuhan yang berkaitan dengan peneguhan informasi, pengetahuan, dan pemahaman melalui lingkungan belajar. Kebutuhan ini berdasar pada hasrat untuk memahami dan menguasai lingkungan belajar, juga memuaskan rasa penasaran kita dan dorongan untuk penyelidikan kita, (2) kebutuhan afektif, yakni kebutuhan yang berkaitan dengan peneguhan pengalaman-pengalaman yang 
estetis, menyenangkan, dan emosional, (3) kebutuhan pribadi secara integratif, yakni kebutuhan yang berkaitan dengan peneguhan kredibilitas, kepercayaan, stabilitas, dan status individual. Hal-hal tersebut diperoleh dari hasrat akan harga diri, (4) kebutuhan sosial secara integratif, yakni kebutuhan yang berkaitan dengan peneguhan kontak dengan keluarga, teman, dan dunia. Hal-hal tersebut berdasarkan hasrat untuk berafiliasi, (5) kebutuhan pelepasan, yakni kebutuhan yang berkaitan dengan menghindarkan tekanan, ketegangan, dan hasrat keanekaragaman.

Menurut Sudjana (dalam Uno, 2011) terdapat enam karakteristik siswa yang memiliki motivasi belajar tinggi, yaitu: (1) Kesenangan atau kenikmatan untuk belajar, berarti menaruh perhatian dan minat terhadap kegiatan-kegiatan belajar dan merasa senang mengerjakan tugas-tugas sekolah dan rumah, (2) orientasi terhadap penguasaan materi, suatu kemampuan yang dimiliki siswa dalam menguasai materi-materi yang didapat di kelas, (3) hasrat ingin tahu, keinginan siswa dalam mencari hal-hal baru, (4) keuletan dalam mengerjakan tugas, siswa memusatkan sepenuhnya untuk menyelesaikan tugas dan tidak mudah menyerah atau putus asa, (5) keterlibatan pada tugas, siswa tekun dalam mengerjakan tugas, berkonsentrasi pada tugas dan meluangkan waktu untuk belajar, (6) orientasi terhadap tugas-tugas yang menantang, sulit dan baru. Motivasi belajar berkaitan dengan ketertarikan siswa terhadap belajar secara mandiri dengan menggunakan sistem E-learning. Berdasarkan kebutuhan siswa dalam menerima ilmu, maka komunikasi pembelajaran sistem E-learning merupakan sebuah dorongan untuk siswa agar semakin termotivasi dalam belajar.

Oleh karena itu untuk mengatahui seberapa besar hubungan antara komunikasi pembelajaran menggunakan sistem e-learning dengan motivasi belajar siswa, penelitian ini memiliki tujuan sebagai berikut: (1) untuk mengetahui pelaksanaan komunikasi pembelajaran menggunakan sistem e-learning, (2) untuk mengetahui motivasi belajar siswa, (3) untuk mengetahui apakah terdapat hubungan antara komunikasi pembelajaran menggunakan sistem e-learning dengan motivasi belajar siswa.

Gambar 1. Hubungan Komunikasi Pembelajaran Sistem E-learning Dengan Motivasi Belajar Siswa

\section{Variabel X \\ Komunikasi Pembelajaran Sistem E- Learning}

X.1 Karakteristik komunikasi pembelajaran sistem e-learning

1. Memberikan pengalaman belajar yang berbeda dan bervariasi.

2. Meningkatkan kemampuan siswa dalam teknologi informasi dan komunikasi.

3. Menciptakan suasana belajar yang menyenangkan.

4. Menjadikan belajar lebih efisien dan bermakna.

5. Komunikasi pembelajaran dilakukan dimana saja dan kapan saja.

X.2 Metode Penyampaian Pesan Melalui Internet (e-learning)
1. Chatting
2. Video online
3. Media Sosial
4. Digital Library

\section{Variabel Y Motivasi Belajar}

\section{Y.1 Kebutuhan Kognitif}

1. Kebutuhan pengetahuan.

2. Kebutuhan pemahaman.

3. Kemampuan menganalisis

\section{Y.2 Kebutuhan Afektif}

1. Kebutuhan perhatian.

2. Kebutuhan kenyamanan. 


\section{MATERI DAN METODE}

Penelitian ini menggunakan metode asosiatif dengan pendekatan kuantitatif. Penelitian dilakukan di SMK Wikrama Kota Bogor dengan populasi penelitian adalah siswa SMK Wikrama Kota Bogor kelas X. Penarikan sampel dilakukan dengan menggunakan teknik simple random sampling. Penentuan sampel menggunakan rumus Taro Yamane dengan tingkat kepercayaan (sampling error) 10\%, jumlah sampel penelitian sebanyak 83 siswa. Data penelitian dikumpulkan berdasarkan data primer dan data sekunder. Pengumpulan data primer dilakukan melalui penyebaran kuesioner, wawancara dan observasi. Sedangkan data sekunder dikumpulkan dari artikel, website, dan dokumen yang relevan. Data penelitian dianalisis dengan prosedur statistik menggunakan Skala Likert untuk melakukan pengukuran terhadap data ordinal. Skala pengukuran ini bertujuan untuk mengkualifikasi data dari reliabilitasnya suatu variabel. Data ordinal tersebut kemudian akan dianalisis menggunakan rumus statistik koefisien korelasi tata jenjang Rank Spearman.

\section{HASIL DAN PEMBAHASAN}

Karakteristik responden berdasarkan jenis kelamin, usia, program keahlian, perangkat teknologi yang dimiliki, aplikasi media yang digunakan, sumber keterampilan, intensitas penggunaan komputer dalam kegiatan belajar dan tempat melaksanakan kegiatan belajar dengan sistem e-learning Sebagaimana Tabel 1 berikut ini. 
Tabel 1. Jumlah dan Presentase Siswa SMK Wikrama Kota Bogor Berdasarkan Karakteristik Responden

\begin{tabular}{|c|c|c|c|}
\hline \multicolumn{2}{|c|}{ Karakteristik Responden } & \multirow{2}{*}{$\frac{\text { Jumlah }}{40}$} & \multirow{2}{*}{$\frac{\text { Presentase }}{48 \%}$} \\
\hline Jenis Kelamin & Pria & & \\
\hline & Wanita & 43 & $52 \%$ \\
\hline & Total & 83 & $100 \%$ \\
\hline \multirow[t]{4}{*}{ Usia } & 14 Tahun & 9 & $11 \%$ \\
\hline & 15 Tahun & 67 & $81 \%$ \\
\hline & 16 Tahun & 7 & $8 \%$ \\
\hline & Total & 83 & $100 \%$ \\
\hline \multirow[t]{5}{*}{ Program Keahlian } & $\begin{array}{c}\text { Rekayasa Perangkat Lunak } \\
\text { (RPL) }\end{array}$ & 21 & $25 \%$ \\
\hline & Multimedia (MM) & 17 & $21 \%$ \\
\hline & $\begin{array}{c}\text { Teknologi Komputer Jaringan } \\
\text { (TKJ) }\end{array}$ & 22 & $26 \%$ \\
\hline & Administrasi Perkantoran (APK) & 23 & $28 \%$ \\
\hline & Total & 83 & $100 \%$ \\
\hline Perangkat Teknologi & Laptop & 47 & $33 \%$ \\
\hline Media Komunikasi yang & PC (Personal Computer) & 23 & $16 \%$ \\
\hline Dimiliki & Tablet/iPad & 21 & $15 \%$ \\
\hline (Lebih Dari Satu) & Smartphone & 50 & $36 \%$ \\
\hline \multicolumn{2}{|r|}{ Total } & 141 & $100 \%$ \\
\hline Aplikasi Teknologi Media & Media Sosial (edmodo) & 5 & $6 \%$ \\
\hline Komunikasi yang & Chatting \& Edmodo & 9 & $11 \%$ \\
\hline \multirow[t]{4}{*}{ Digunakan } & Digital Library \& Edmodo & 25 & $30 \%$ \\
\hline & $\begin{array}{l}\text { Digital Library, Chatting dan } \\
\text { Edmodo }\end{array}$ & 41 & $49 \%$ \\
\hline & Media Flash \& Edmodo & 3 & $4 \%$ \\
\hline & Total & 83 & $100 \%$ \\
\hline \multirow{5}{*}{ Sumber Keterampilan } & Belajar Sendiri & 58 & $70 \%$ \\
\hline & Mengikuti Kursus & 10 & $12 \%$ \\
\hline & Di Sekolah & 15 & $18 \%$ \\
\hline & Total & 83 & $100 \%$ \\
\hline & 1-2 kali per minggu & 0 & $0 \%$ \\
\hline Intensitas Penggunaan & 3-4 kali per minggu & 45 & $54 \%$ \\
\hline Komputer dalam Kegiatan & $>4$ kali perminggu & 38 & $46 \%$ \\
\hline \multicolumn{4}{|l|}{ Belajar } \\
\hline & Total & 83 & $100 \%$ \\
\hline Tempat Melaksanakan & Di Kelas & 44 & $37 \%$ \\
\hline Kegiatan Belajar dengan & Di Laboratorium Komputer & 45 & $38 \%$ \\
\hline \multirow[t]{2}{*}{$\begin{array}{l}\text { Sistem E-learning } \\
\text { (Lebih Dari Satu) }\end{array}$} & Di Luar Kelas/Rumah/Warnet & 31 & $25 \%$ \\
\hline & Total & 120 & $100 \%$ \\
\hline Akses Internet Untuk & Di Sekolah & 65 & $78 \%$ \\
\hline \multirow{3}{*}{ Kegiatan Belajar } & Di Rumah & 18 & $22 \%$ \\
\hline & Di Warnet & 0 & $0 \%$ \\
\hline & Total & 83 & $100 \%$ \\
\hline
\end{tabular}


Berdasarkan Tabel 1 jenis kelamin responden sebagian besar wanita, dengan rentang usia sebagian besar berusia 15 tahun. Sedangkan program keahlian sebagian besar jurusan Administrasi Perkantoran (APK) yang merupakan jurusan andalan dari SMK Wikrama. Perangkat teknologi media komunikasi yang dimiliki siswa, mayoritas memiliki perangkat teknologi sendiri yaitu smartphone, laptop, pc, dan tablet/ipad. Perangkat teknologi yang dimiliki siswa tersebut digunakan untuk menunjang kegiatan belajar siswa di sekolah. Perangkat media tersebut digunakan untuk mengakses aplikasi media komunikasi dalam e-learning yaitu digital library, chatting \& edmodo. Digital Library merupakan perpustakaan berbasis digital yang disediakan oleh SMK Wikrama sehingga siswa dapat mengakses bahan ajar melalui digital library. Chatting merupakan fasilitas komunikasi melalui media aplikasi kepada sesama siswa dan guru yang bisa dimanfaatkan untuk berdiskusi dalam forum $e$ learning. Sedangkan edmodo merupakan fasilitas media sosial yang berbasis edukasi yang berfungsi untuk bertukar informasi mengenai materi belajar dan berdiskusi. Keahlian yang dimiliki siswa sebagian besar berasal dari belajar sendiri, perangkat media komunikasi berbasis internet sudah dikuasai siswa sejak SMP Hal ini membuat keahlian siswa menguasai e-learning dengan cepat, ditambah intensitas siswa dalam menggunakan komputer sebagai media pembelajaran sebagian besar 3-4 kali dalam seminggu mempengaruhi keahlian siswa dalam menguasai e-learning, serta tempat melaksanakan sistem e-learning yang dilakukan siswa sebagian besar dilakukan di laboratorium komputer dan di kelas. Akses internet yang digunakan untuk kegiatan belajar sebagian besar dilakukan dengan wi-fi sekolah dengan kapasitas kecepatan hingga $20 \mathrm{mbps}$, akses internet dengan kecepatan seperti itu membuat siswa menjadi lebih nyaman disekolah dan membuat siswa lebih suka menghabiskan waktu disekolah.

\section{Komunikasi Pembelajaran Sistem E- learning}

Berikut data primer yang terkumpul dari responden terhadap komunikasi pembelajaran sistem e-learning dapat dilihat pada tabel 2 .
Deskripsi data menggunakan metode distribusi frekuensi terhadap semua peubah penelitian (variebel penelitian).Dimensi pertama yaitu karakteristik media pembelajaran sistem $e$ learning. Dalam karakteristik tersebut terbagi 5 indikator yang terdiri dari: (1) Pengalaman Belajar yang Berbeda dan Bervariasi, indikator ini diukur dari sistem e-learning memberikan pengalaman belajar yang sangat berbeda dengan sistem konvensional dan kegiatan pembelajaran dengan sistem e-learning sangat bervariasi. (2) Kemampuan Siswa Dalam Pemanfaatan Teknologi Informasi dan Komunikasi, indikator ini diukur dari pembelajaran dengan sistem e-learning meningkatkan kemampuan dalam pemanfaatan teknologi informasi dan komunikasi, pembelajaran dengan sistem e-learning menjadikan terbiasa dalam memanfaatkan jaringan internet untuk mencari informasi, dan pembelajaran dengan sistem e-learning merangsang kreativitas dalam memanfaatkan teknologi informasi dan komunikasi. (3) Suasana Belajar, indikator ini diukur dari Pembelajaran dengan sistem e-learning dapat membuat suasana lebih menyenangkan, sistem e-learning meningkatkan semangat belajar, sistem e-learning tidak membosankan. (4) Efisiensi dan Makna Pembelajaran, indikator ini diukur dari sistem e-learning mengurangi penggunaan buku pelajaran, mengurangi penggunaan buku catatan, belajar menjadi lebih mudah, meningkatkan kemampuan mengatasi masalah dan menumbuhkan kemandirian. (5) Waktu dan Tempat Belajar, indikator ini diukur dari sistem e-learning dilaksanakan tidak harus pada jam sekolah dan di dalam atau di luar sekolah.Dimensi kedua yaitu Metode Penyampaian Pesan Melalui Internet (E-learning). Dimensi ini diukur dari penyampaian pesan berupa bahan ajar berbasis e-learning sangat bervariasi, penyajian sangat menarik dan tidak membosankan, bahan ajar sangat jelas dan mudah dimengerti, membantu siswa untuk mendalami materi, meningkatkan pemahaman siswa. 
Tabel 2 Komunikasi Pembelajaran Sistem E-learning Di SMK Wikrama Kota Bogor

\begin{tabular}{|c|c|c|c|c|c|c|c|c|c|}
\hline \multirow[t]{2}{*}{ NO } & \multirow[t]{2}{*}{ Indikator } & \multicolumn{5}{|c|}{ Frekuensi } & \multirow[t]{2}{*}{$F(x)$} & \multirow[t]{2}{*}{$\left.\sum \mathrm{f}(\mathrm{x})\right) / \mathrm{N}$} & \multirow[t]{2}{*}{ Kriteria } \\
\hline & & SS & $\mathrm{S}$ & $\overline{\mathrm{R}}$ & TS & STS & & & \\
\hline \multicolumn{10}{|c|}{ Pengalaman Belajar yang Berbeda Dan Bervariasi } \\
\hline 1 & $\begin{array}{l}\text { Pembelajaran dengan sistem e-learning sangat } \\
\text { berbeda dengan sistem pembelajaran komunikasi } \\
\text { tatap muka. }\end{array}$ & 27 & 38 & 16 & 2 & 0 & 339 & 4,08 & Baik \\
\hline 2 & $\begin{array}{l}\text { Kegiatan pembelajaran dengan sistem e-learning } \\
\text { sangat bervariasi. }\end{array}$ & 23 & 35 & 23 & 2 & 0 & 328 & 3,95 & Baik \\
\hline \multicolumn{10}{|c|}{ Kemampuan Siswa Dalam Pemanfaatan TIK } \\
\hline 3 & $\begin{array}{l}\text { Kemampuan dalam menggunakan perangkat } \\
\text { teknologi informasi dan komunikasi }\end{array}$ & 25 & 39 & 19 & 0 & 0 & 338 & 4,07 & Baik \\
\hline 4 & $\begin{array}{l}\text { Menjadikan terbiasa dalam memanfaatkan } \\
\text { jaringan internet untuk mencari informasi }\end{array}$ & 20 & 40 & 20 & 3 & 0 & 326 & 3,93 & Baik \\
\hline 5 & $\begin{array}{l}\text { Merangsang kreativitas dalam memanfaatkan } \\
\text { teknologi informasi dan komunikasi }\end{array}$ & 18 & 38 & 22 & 5 & 0 & 318 & 3,83 & Baik \\
\hline \multicolumn{10}{|c|}{ Suasana Belajar } \\
\hline 6 & Membuat suasana belajar lebih menyenangkan & 15 & 45 & 22 & 1 & 0 & 323 & 3,89 & Baik \\
\hline 7 & Meningkatkan semangat belajar & 27 & 23 & 25 & 8 & 0 & 318 & 3,83 & Baik \\
\hline 8 & $\begin{array}{l}\text { Pembelajaran dengan sistem e-learning tidak } \\
\text { membosankan }\end{array}$ & 4 & 15 & 29 & 35 & 0 & 237 & 4,14 & Baik \\
\hline \multicolumn{10}{|c|}{ Efisiensi dan Makna Pembelajaran } \\
\hline 9 & Mengurangi penggunaan buku pelajaran & 39 & 25 & 16 & 3 & 0 & 349 & 4,2 & Baik \\
\hline 10 & Mengurangi penggunaan buku catatan & 36 & 32 & 15 & 0 & 0 & 353 & 4,25 & $\begin{array}{l}\text { Sangat } \\
\text { Baik }\end{array}$ \\
\hline 11 & $\begin{array}{l}\text { Sistem e-learning membuat belajar menjadi } \\
\text { semakin mudah }\end{array}$ & 26 & 28 & 20 & 0 & 0 & 302 & 3,85 & Baik \\
\hline 12 & Meningkatkan kemampuan mengatasi masalah & 15 & 33 & 16 & 19 & 0 & 293 & 3,53 & Baik \\
\hline 13 & Menumbuhkan kemandirian dalam belajar & 37 & 20 & 20 & 6 & 0 & 337 & 4,06 & Baik \\
\hline \multicolumn{10}{|c|}{ Waktu dan Tempat belajar } \\
\hline 14 & $\begin{array}{l}\text { Sistem e-learning tidak harus dilaksanakan pada } \\
\text { jam pelajaran di sekolah }\end{array}$ & 30 & 25 & 28 & 0 & 0 & 334 & 4,02 & Baik \\
\hline 15 & $\begin{array}{l}\text { Sistem e-learning dilaksanakan di dalam dan di } \\
\text { luar sekolah }\end{array}$ & 20 & 32 & 24 & 6 & 0 & 312 & 3,78 & Baik \\
\hline \multicolumn{10}{|c|}{ Metode Penyampaian Pesan Melalui Internet (E-learning) } \\
\hline 16 & $\begin{array}{l}\text { Bahan ajar berbasis sistem e-learning sangat } \\
\text { bervariasi }\end{array}$ & 26 & 38 & 19 & 0 & 0 & 339 & 4,08 & Baik \\
\hline 17 & $\begin{array}{l}\text { Penyajian bahan ajar berbasis sistem e-learning } \\
\text { sangat menarik dan tidak membosankan }\end{array}$ & 31 & 37 & 15 & 0 & 0 & 348 & 4,19 & Baik \\
\hline 18 & $\begin{array}{l}\text { Bahan ajar berbasis sistem e-learning sangat jelas } \\
\text { dan mudah dimengerti }\end{array}$ & 18 & 25 & 30 & 10 & 0 & 300 & 3,61 & Baik \\
\hline 19 & $\begin{array}{l}\text { Variasi penyajian bahan ajar berbasis sistem } e \text { - } \\
\text { learning membantu untuk lebih mendalami materi } \\
\text { pelajaran }\end{array}$ & 26 & 33 & 17 & 7 & 0 & 327 & 3,94 & Baik \\
\hline 20 & $\begin{array}{l}\text { Variasi penyajian bahan ajar berbasis sistem } e^{-} \\
\text {learning meningkatkan pemahaman setiap materi } \\
\text { pelajaran }\end{array}$ & 22 & 39 & 20 & 2 & 0 & 330 & 3,97 & Baik \\
\hline \multicolumn{7}{|c|}{ Jumlah Angka Penafsiran } & & 79,2 & \multirow[t]{2}{*}{ Baik } \\
\hline & Rata-rata Angka Penafsiran & & & & & & & 3,96 & \\
\hline
\end{tabular}

Sumber: Hasil Penelitian 2015 
Berdasarkan hasil penelitian, sebagian besar responden setuju komunikasi pembelajaran dengan sistem e-learning memberikan pengalaman belajar yang berbeda yang merupakan sistem baru yang sejak SD-SMP siswa tidak pernah menggunakan belajar dengan sistem e-learning, dengan kehadiran $e$ learning membuat belajar menjadi semakin bervariasi karena perpaduan belajar sistem $e$ learning yang mengutamakan perangkat teknologi dalam belajar digabungkan dengan masih adanya sistem konvensional maka $e$ learning memberikan variasi yang baru. Meningkatkan kemampuan siswa dalam pemanfaatan teknologi informasi dan komunikasi sebagian besar siswa setuju sistem e-learning dapat meningkatkan kemampuan dalam memanfaatkan teknologi komputer dan internet sehingga meningkatkan pula kreativitas dalam pemanfaatan teknologi informasi dan komunikasi. Membuat suasana belajar menjadi menyenangkan, sebagian besar siswa setuju jika sistem e-learning membuat suasana belajar lebih menyenangkan, meningkatkan semangat belajar dan tidak membosankan, namun dengan sistem $e$ learning siswa cenderung lebih fokus dengan perangkat teknologi masing-masing sehingga siswa lebih mandiri. Efisiensi dan Makna Pembelajaran, sebagian besar siswa setuju jika dengan sistem e-learning mengurangi penggunaan buku catatan dan buku pelajaran namun tidak menghilangkan sepenuhnya siswa tetap menggunakan buku catatan hanya tidak sebanyak saat belajar dengan sistem konvensional, oleh karena itu sistem e-learning membuat belajar menjadi semakin mudah dan menumbuhkan kemandirian dalam belajar. Waktu dan Tempat Belajar, sebagian besar siswa tidak tergantung pada jam pelajaran disekolah karena mereka bisa belajar dengan $e$ learning kapan saja selama masih terhubung dengan jaringan internet, serta dapat dilaksanakan di dalam ataupun luar sekolah. Secara metode penyampaian pesanpun sebagian besar siswa SMK Wikrama setuju sistem e-learning memberikan bahan ajar yang bervariasi, penyajian bahan ajar yang menarik sehingga dapat meningkatkan pemahaman setiap materi pelajaran, meskipun melalui media internet tapi penyajian bahan ajar yang menarik membuat siswa terangsang ingin mendalami materi pelajaran serta meningkatkan pemahaman siswa.

\section{Motivasi Belajar}

Berikut data primer yang terkumpul dari responden terhadap motivasi belajar siswa dapat dilihat pada tabel 3. Deskripsi data menggunakan metode distribusi frekuensi terhadap semua peubah penelitian (variebel penelitian). Dimensi pertama yaitu Kebutuhan Kognitif yang memiliki tiga indikator yaitu (1) Kebutuhan Pengetahuan diukur dari pembelajaran dengan sistem e-learning meningkatkan minat belajar, mendapatkan lebih banyak pengetahuan dan merangsang kemampuan untuk mengembangkan ide dan gagasan. (2) Kebutuhan Pemahaman diukur dari belajar dengan sistem e-learning meningkatkan kemampuan dalam memahami setiap persoalan dalam materi belajar. (3) Kebutuhan Analisis diukur dari belajar dengan sistem e-learning meningkatkan kemampuan dalam menganalisis masalah. Dimensi kedua yaitu Kebutuhan Afektif mengukur sikap siswa terhadap sistem e-learning, dan kebutuhan afektif memiliki dua indikator yaitu (1) Kebutuhan Perhatian diukur dari belajar dengan sistem e-learning membuat siswa menjadi lebih fokus dalam belajar, mengubah sikap menjadi tidak tergantung pada aktivitas belajar disekolah, serta membuat belajar tidak harus selalu tergantung pada kehadiran guru. (2) Kebutuhan Kenyamanan diukur dari belajar dengan sistem e-learning membuat belajar menjadi menyenangkan dan mendapatkan pengalaman belajar yang lebih menarik. 
Tabel 3. Tanggapan Responden Tentang Motivasi Belajar Siswa Di SMK Wikrama Kota Bogor

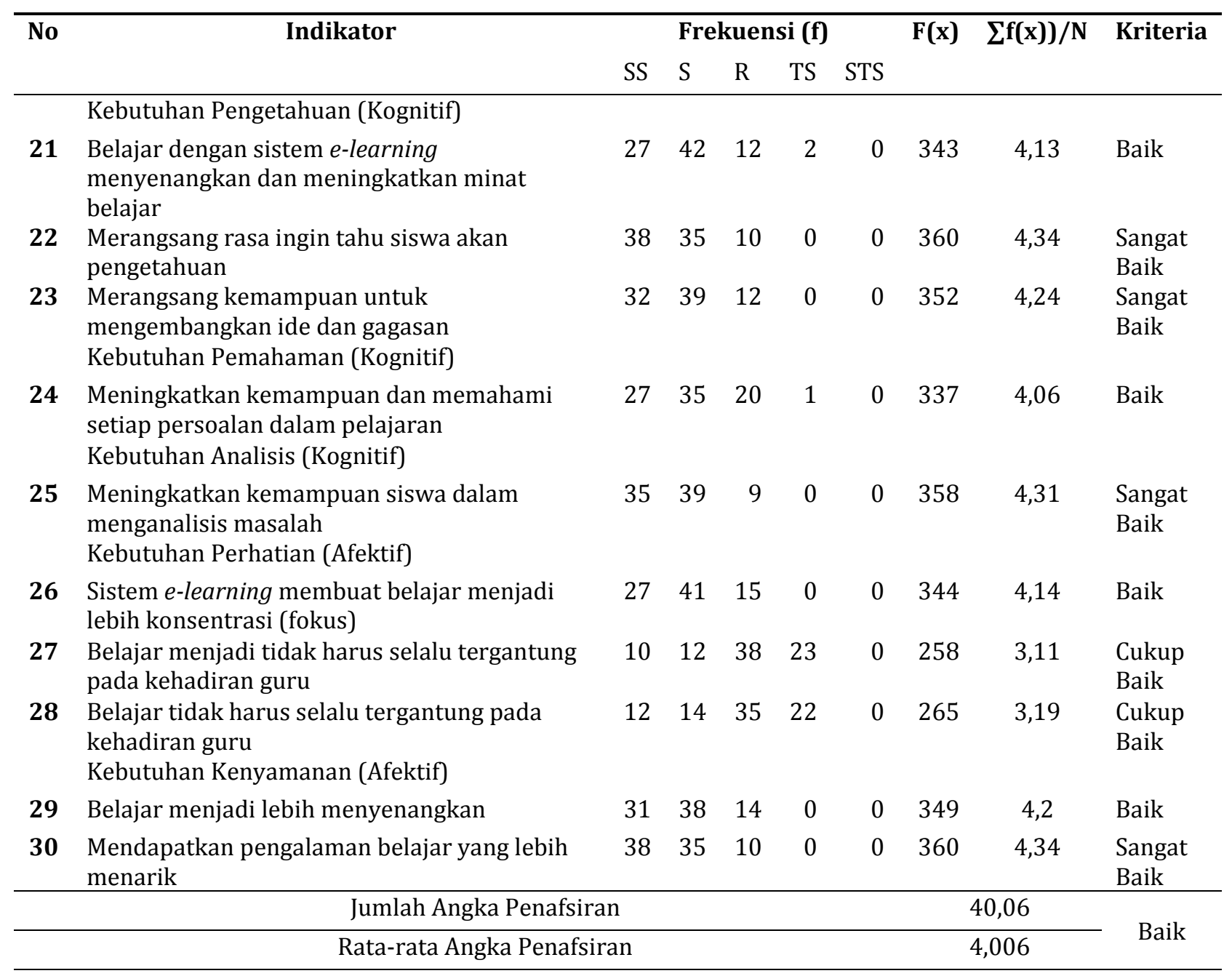

Sumber: Hasil Penelitian 2015 
Berdasarkan hasil penelitian sebagian besar menyatakan setuju komunikasi pembelajaran sistem e-learning mempengaruhi motivasi belajar. Kebutuhan kognitif yang terdiri dari kebutuhan pengetahuan siswa tentang materi belajar setelah menggunakan sistem e-learning sudah terpenuhi dengan baik, siswa merasa sistem e-learning menyenangkan dan meningkatkan minat balajar karena langsung terhubung dengan sistem internet merangang minat untuk mendapatkan lebih banyak pengetahuan. Kebutuhan pemahaman akan materi belajar setelah menggunakan sistem $e$ learning sudah terpenuhi dengan baik, karena siswa merasa paham dengan semua materi belajar yang diajarkan melalui e-learning sehingga meningkatkan kemampuan siswa. serta kebutuhan analisis siswa dalam menganalisa materi belajar setelah menggunakan sistem e-learning sudah terpenuhi dengan baik, siswa merasa sistem $e$ learning efektif meningkatkan kemampuan siswa dalam menganalisis masalah. Kebutuhan afektif yang terdiri dari kebutuhan perhatian siswa tentang adanya perhatian dari sekolah kepada siswa selama menggunakan sistem $e$ learning cukup terpenuhi, siswa merasa sistem e-learning membuat siswa menjadi lebih fokus, pembelajaran yang tidak tergantung aktivitas belajar disekolah membuat siswa menjadi lebih mandiri dan itu merupakan bentuk dari kebutuhan perhatian. Kebutuhan kenyamanan siswa dalam menggunakan sistem e-learning sudah terpenuhi dengan baik, siswa merasa belajar dengan sistem e-learning menyenangkan dan mendapatkan pengalaman belajar yang lebih menarik sehingga siswa merasa lebih nyaman belajar dengan sistem $e$ learning.

Hubungan Antar Komunikasi Pembelajaran Sistem E-learning dengan Motivasi Belajar Siswa

Analisis hubungan komunikasi pembelajaran dengan sistem e-learning dengan motivasi belajar siswa. Berdasarkan uji korelasi data ordinal Rank Spearman, diperoleh gambaran hubungan variabel komunikasi pembelajaran sistem e-learning dengan variabel motivasi belajar siswa yang diuraikan pada tabel 4 . 
Tabel 4. Hubungan Komunikasi Pembelajaran Sistem E-learning Dengan Motivasi Belajar Siswa

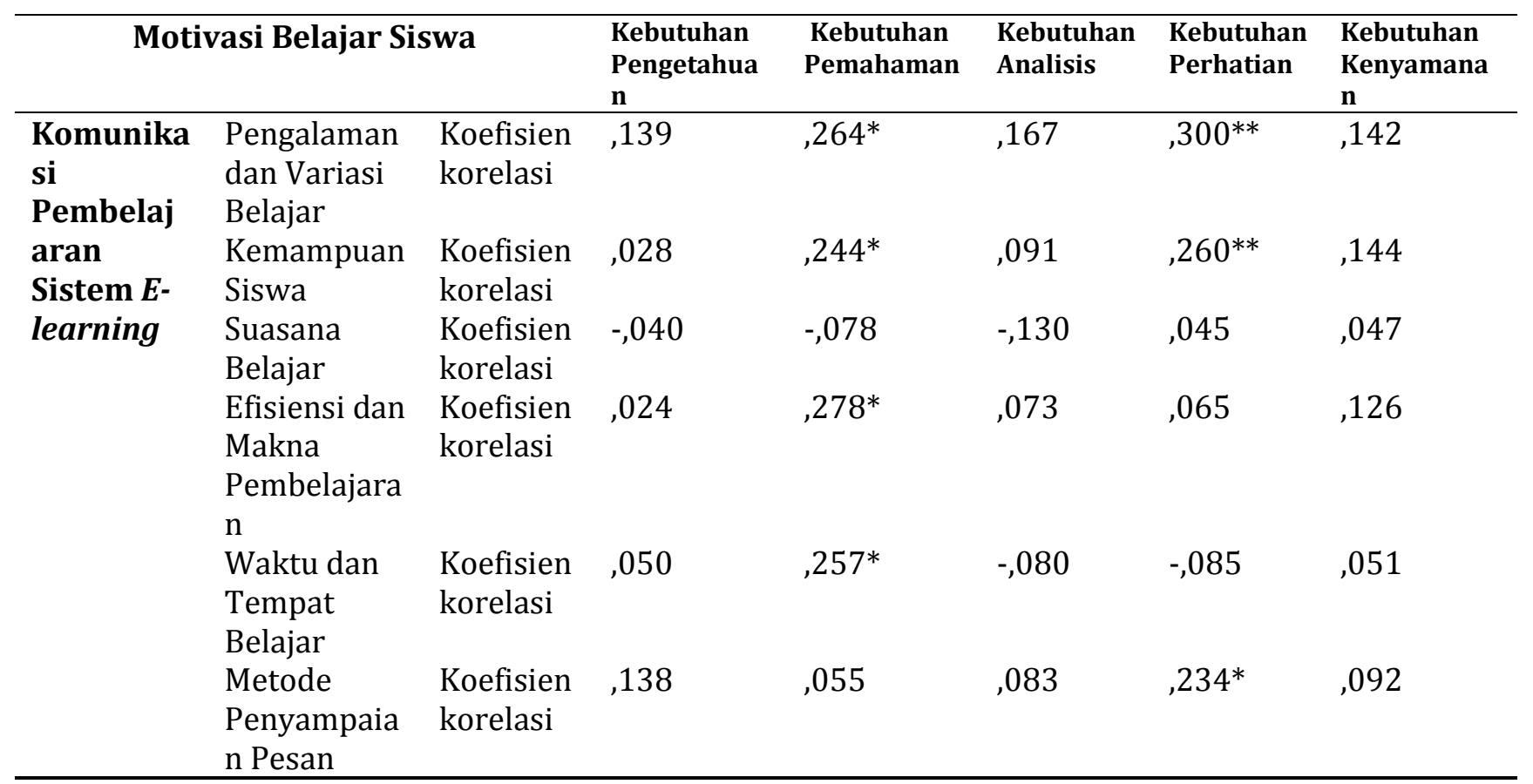

*.Hubungan nyata pada taraf 0.05 (2-arah). ${ }^{* *}$.Hubungan nyata pada taraf 0.01 (2-arah)

Sumber: Penelitian 2015

1. Indikator Pengalaman dan Variasi Belajar memiliki hubungan yang nyata dengan kebutuhan pemahaman, yang bermakna adanya hubungan positif di pengalaman siswa menggunakan sistem e-learning dan metode belajar menjadi semakin bervariasi sehingga meningkatkan siswa dalam meningkatkan kemampuan siswa dalam menganalisa pelajaran. Hubungan yang sangat nyata dengan kebutuhan perhatian, yang bermakna berkat pengalaman yang berbeda dan bervariasi mendorong siswa lebih konsentrasi dalam belajar dan siswa diajarkan agar tidak tergantung dalam kegiatan belajar disekolah dan kehadiran guru. Sedangkan pengalaman dan variasi belajar memiliki hubungan yang sangat lemah dan tidak nyata dengan kebutuhan pengetahuan, kebutuhan analisis dan kebutuhan kenyamanan karena pengalaman berbeda dan bervariasi tidak mempengaruhi siswa dalam meningkatkan minat belajar, menganalisis dan kenyamanan.

2. Indikator Kemampuan Siswa memiliki hubungan yang nyata dengan kebutuhan pemahaman yang bermakna bahwa sistem e-learning meningkatkan kemampuan siswa dalam pemanfaatan teknologi informasi sehingga meningkatkan juga kemampuan untuk memahami setiap persoalan dalam belajar. Hubungan yang sangat nyata dengan kebutuhan perhatian yang bermakna peningkatan kemampuan membuat siswa lebih fokus dalam belajar sehingga tidak tergantung dengan kehadiran guru dan aktivitas di sekolah. Sedangkan kemampuan siswa memiliki hubungan sangat lemah dan tidak nyata dengan kebutuhan pengetahuan , kebutuhan analisis dan kebutuhan kenyamanan karena kemampuan siswa tidak meningkatkan minat belajar, tidak meningkatkan kemampuan menganalisis dan tingkat kenyamanan.

3. Indikator Suasana Belajar memiliki hubungan yang sangat lemah bahkan negatif serta tidak nyata pada semua indikator motivasi belajar yaitu: kebutuhan pengetahuan, kebutuhan pemahaman, kebutuhan analisis, kebutuhan perhatian dan kebutuhan kenyamanan karena suasana belajar dalam e-learning membutuhkan kemandirian dan cenderung masing-masing sehingga tidak memiliki hubungan dengan peningkatan minat belajar. 
4. Indikator Efisiensi dan Makna Pembelajaran memiliki hubungan nyata dengan indikator kebutuhan pemahaman, yang bermakna berkurangnya penggunaan buku catatan dan buku pelajaran membuat siswa lebih bisa mengeksplorasi materi melalui internet sehingga meningkatkan kemampuan dalam memahami dalam setiap persoalan dalam pelajaran. Sedangkan efisiensi dan makna pembelajaran memiliki hubungan yang sangat lemah dan tidak nyata dengan kebutuhan pengetahuan, kebutuhan analisis, kebutuhan perhatian dan kebutuhan kenyamanan karena berkurangnya penggunaan buku catatan tidak meningkatkan minat belajar, meningkatkan kemampuan analisis, tidak membuat siswa menjadi lebih fokus dan tidak memiliki kenyamanan.

5. Indikator Waktu dan Tempat Belajar memiliki hubungan nyata dengan indikator kebutuhan pemahaman, yang bermakna sistem e-learning yang tidak tergantung pada jam belajar dan tempat belajar membuat siswa lebih fleksibel dalam belajar sehingga meningkatkan tingkat pemahaman dalam setiap persoalan dalam belajar. Sedangkan waktu dan tempat belajar memiliki hubungan yang sangat lemah dan tidak nyata dengan kebutuhan pengetahuan, kebutuhan analisis, kebutuhan perhatian dan kebutuhan kenyamanan karena kebebasan jam belajar dan tempat belajar tidak meningkatkan minat belajar, meningkatkan analisis, membuat siswa menjadi tidak fokus dan tidak merasa memiliki kenyamanan.

6. Indikator Metode Penyampaian Pesan memiliki hubungan nyata dengan indikator kebutuhan perhatian, yang bermakna penyajian bahan e-learning yang bervariasi membat siswa menjadi lebih fokus dan mandiri. Sedangkan metode penyampaian pesan memiliki hubungan sangat lemah dan tidak nyata dengan kebutuhan pengetahuan, kebutuhan pemahaman, kebutuhan analisis dan kebutuhan kenyamanan karena penyajian bahan melalui sistem e-learning tidak meningkatkan minat belajar, pemahaman, analisis serta kenyamanan bagi siswa.

\section{Uji Hipotesis}

Uji hipotesis ini untuk mengetahui hubungan antara komunikasi pembelajaran sistem $e$ learning dengan motivasi belajar siswa secara menyeluruh berdasarkan uji korelasi rank spearman, yang dapat dilihat pada tabel 5 .

Tabel 5. Hubungan Komunikasi Pembelajaran Sistem E-learning Dengan Motivasi Belajar Siswa

\begin{tabular}{|c|c|c|c|c|}
\hline & & & $\mathrm{X}$ & $\mathrm{Y}$ \\
\hline \multirow[t]{6}{*}{ Spearman's rho } & \multirow{3}{*}{$\begin{array}{l}\mathrm{X} \\
\text { (Komunikasi } \\
\text { pembelajaran sistem E- } \\
\text { learning) }\end{array}$} & $\begin{array}{l}\text { Koefisien } \\
\text { Korelasi }\end{array}$ & 1,000 & ,287** \\
\hline & & Sig. (2-arah) & & 008 \\
\hline & & $\mathrm{N}$ & 83 & 83 \\
\hline & $\begin{array}{l}\text { Y } \\
\text { (Motivasi Belajar Siswa) }\end{array}$ & $\begin{array}{l}\text { Koefisien } \\
\text { Korelasi }\end{array}$ &, $287^{* *}$ & 1,000 \\
\hline & & Sig. (2-arah) & ,008 & \\
\hline & & $\mathrm{N}$ & 83 & 83 \\
\hline ** Hubungan ny & taraf 0.01 (2-arah) & Suml & nelitian 2 & \\
\hline
\end{tabular}


Berdasarkan tabel 5, analisis rank spearman hubungan komunikasi pembelajaran sistem $e$ learning dengan motivasi belajar didapat koefisien sebesar 0,287**. Maka korelasi diantara kedua variabel $\mathrm{X}$ (komunikasi pembelajaran sistem e-learning) dan variabel $\mathrm{Y}$ (motivasi belajar) adalah rendah, namun memiliki hubungan yang sangat nyata pada taraf 0,01. Kesimpulannya hubungan komunikasi pembelajaran sistem e-learning dengan motivasi belajar siswa memiliki hubungan yang rendah dan sangat nyata, serta menunjukan hubungan positif.

\section{Uji Signifikansi}

Untuk menentukan diterima atau ditolaknya hipotesis maka dilakukan pengujian koefisien korelasi dengan uji t.

$$
t=0,287 \sqrt{\frac{81}{0,177}} \quad t=6,139
$$

Dari hasil perhitungan diperoleh nilai $t_{\text {hitung }}$ hasil penelitian sebesar 6,139 kemudian nilai $t_{\text {hitung }}$ dibandingkan dengan $t_{\text {tabel }}$ distribusi $t$ dengan taraf signifikan $10 \% \quad(0,1)$ maka diperoleh nilai $t_{\text {tabel }}$ adalah 1,663. Hal tersebut menunjukan bahwa ternyata $\mathrm{T}_{\text {hitung }}>\mathrm{T}_{\text {tabel. }}$. Dengan demikian maka koefisien korelasi rank spearman nyata (signifikan). Komunikasi pembelajaran dengan sistem e-learning memiliki hubungan dengan motivasi belajar, dan hasil ini adalah nyata.

\section{KESIMPULAN DAN SARAN}

\section{Kesimpulan}

Komunikasi pembelajaran dengan sistem $e$ learning memberikan pengalaman yang berbeda dan bervariasi kepada siswa. Siswa dituntut untuk aktif berkomunikasi menggunakan teknologi informasi dan komunikasi. Sistem e-learning membuat suasana belajar siswa lebih konsentrasi karena siswa fokus pada perangkat komputer masingmasing. Pembelajaran dengan sistem e-learning efisien karena materi sudah tersedia di aplikasi e-learning yang dapat diunduh dan dipelajari oleh siswa kapan saja dan dimana saja. Pembelajaran dengan sistem e-learning meningkatkan kemampuan siswa dalam mengatasi masalah dan kemandirian dalam belajar.

Motivasi belajar siswa dengan sistem $e$ learning dalam hal kebutuhan kognitif dan afektif dapat terpenuhi dengan baik. Kebutuhan kognitif meliputi kebutuhan pengetahuan, pemahaman dan analisis. Sistem e-learning merangsang rasa ingin tahu siswa dalam mendalami materi pembelajaran karena dapat diakses dari berbagai sumber melalui jaringan internet. Sistem e-learning dapat meningkatkan pemahaman siswa walaupun beberapa mata pelajaran masih lebih efektif apabila dijelaskan melalui komunikasi tatap muka. Sistem e-learning juga meningkatkan kemampuan analisis karena siswa terbiasa menyelesaikan masalah sendiri.

Kebutuhan afektif meliputi kebutuhan perhatian dan kenyamanan. Sistem e-learning membuat siswa menjadi lebih fokus dalam belajar, namun siswa masih tergantung pada aktivitas belajar di sekolah, serta kehadiran guru masih dianggap penting. Sistem e-learning membuat suasana menjadi menyenangkan karena penambahan konten-konten permainan yang bersifat edukasi, menambah kenyamanan siswa dalam belajar.

Hubungan komunikasi pembelajaran sistem e-learning dengan motivasi belajar siswa adalah rendah. Hubungan yang rendah disebabkan pemanfaatan media komunikasi sebagai media pembelajaran bukan menjadi hal baru bagi siswa. Namun hubungan yang rendah itu nyata (signifikan). Sistem e-learning memiliki hubungan yang nyata dengan motivasi belajar siswa, khususnya pada kebutuhan pemahaman dan perhatian. Siswa merasa dengan adanya perubahan metode belajar dari konvensional kepada sistem $e$ learning membuat siswa menjadi lebih paham, serta siswa merasa lebih fokus dan konsentrasi dalam belajar.

\section{Saran}

Pihak sekolah diharapkan mampu mengawasi siswa dalam mengakses jaringan internet yang tersedia di sekolah hanya sebatas untuk media pembelajaran dan membuka konten yang positif, bukan untuk membuka konten yang berbau negatif.

Kepada siswa diperlukan kontrol diri dalam penggunaan jaringan internet sehingga tidak berlebihan yang berdampak pada motivasi belajar yang semakin rendah dan kecanduan dengan internet. 


\section{DAFTAR PUSTAKA}

Hanum, N. S. 2013. Keefektifan E-learning Sebagai Media Pembelajaran (Study Evaluasi Model Pembelajaran E-learning SMK Telkom Sandhy Putra Purwokerto). Jurnal Pendidikan Vokasi. Vol. 3. No. 1 : 9295.

Mulyana, Deddy. 2004. Pengantar Ilmu Komunikasi. Jakarta: Remaja Rosdakarya.
Prawiradilaga, D. S, dkk. 2013. Mozaik Teknologi Pendidikan E-learning. Yogyakarta: Kencana.

Rakhmat, Jalaluddin. 2007. Psikologi Komunikasi. Jakarta: Remaja Rosdakarya.

Rohim, Syaiful. 2009. Teori Komunikasi: Prespektif, Ragam dan Aplikasi. Jakarta: Rineka Cipta.

Sugiyono. 2011. Metode Penelitian Administrasi. Bandung: Alfabeta.

Uno, Hamzah B. (2011). Teori Motivasi dan Pengukurannya. Jakarta: Bima Aksara.

http://www.smkwikrama.net $\quad$ (23/03/2015 19:42). 